\title{
Electoral Illiteracy and Democratic Citizenship in Zimbabwe
}

\author{
Monicah Zembere \\ http://dx.doi./org/10.4314/ujah.v21i1.3
}

\section{Abstract}

This paper argues that electoral processes in Africa with special focus on Zimbabwe are never fair due to rampant electoral illiteracy. In this paper, illiteracy is far beyond the inability to read and write but encompasses a high degree of ignorance from not reading. The theory informing arguments in the paper is democratic citizenship. This is a qualitative research where data has been gathered through interviews and observation. Zimbabwe's election processes of 2008, 2013 and 2018 had been used as case studies to substantiate the findings of this study. The major findings are that besides electoral illiteracy, factors such as intimidation, fear, manipulation (vote buying), partisan and hero worshipping also compromise the credibility of elections in Zimbabwe. The other finding is that as long as citizens are not familiar with electoral process of their country, the levels of participation of such people will remain low. In the light of these findings, this research recommends effective active citizenship if electoral crisis in Zimbabwe is to be addressed.

Keywords: Democracy, Democratic Citizenship, Electoral Illiteracy

\section{Introduction}

Elections are the processes that are meant to select candidates for positions in government or political office. They are the basis of representative democracy and one of the acceptable means through 
which leaders are selected in a democratic state (Mapuva 2010). Since elections are the basis through which democratic reforms can be built, the holding of regular elections is therefore a central requirement for democratic qualification and the renewal of the democratic system of any country (Diamond 2005:14). The holding of elections by governments in Africa has not only been credited for the emergence of a democratic continent but is also considered to be of great significance (Lindberg 2006: 139). This paper argues that electoral processes in Africa with special focus on Zimbabwe are never fair due to rampant electoral illiteracy. In this paper, illiteracy is far beyond the inability to read and write but encompasses a high degree of ignorance from not reading. The argument in this paper is that, elections in Africa have been associated with and characterised by vote buying, politically motivated violence and mud-slinging as contending political parties seek to out -manoeuvre each other (Masunungure 2013). Generally, in Africa and particularly in Zimbabwe, the period of elections is characterised by harassment and intimidation of political opponents (Mapuva 2010). In the majority of cases, elections in Zimbabwe have led to violence, re-runs, court cases, and calls for recounts. In all these disturbances, the most vulnerable victim is the voter.

While literacy rate in Zimbabwe is comparatively higher than in other African states, $96 \%$ to be precise, people in Zimbabwe struggle to make informed choices due to lack of education on the voting processes (Mapuva 2010; Zembere 2015). In this regard, the paper draws attention to research on voting processes in Zimbabwe as it seeks to answer the following set of questions: How do Zimbabweans behave at election time? What motivates the people's voting choice? What are the implications of voter education on democratic citizenship? 
In Zimbabwe, elections are run and administered by the Zimbabwe Electoral Commission comprising eight members and whose chairperson is appointed by the President. The Zimbabwe Electoral Commission (ZEC) is/ was established under section 238 of the country's 2013 new constitution. The constitutional functions of ZEC are spelt out in section 239 of the Zimbabwe's 2013 new Constitution as to 'prepare for, conduct and supervise elections' (s 239(a) (Constitution of Zimbabwe 2013). This implies that ZEC ensures elections are conducted 'efficiently, freely, fairly, transparently in accordance with the law' (s 239(b)). Both voter registration and the compilation of voters' rolls fall under the jurisdiction of the ZEC. The Zimbabwe Electoral Commission report to Parliament on the conduct of every election since it is also responsible for voter education, including informing citizens about where and how to register as voters and other related matters. The constitution of Zimbabwe endows ZEC with powers to perform these functions effectively.

An important aspect in this paper is the acknowledgement that elections are part of a democratic process and not democracy themselves. Therefore, it is not enough to have electoral democracy without a liberal democracy. In any case, liberal democracy precedes electoral democracy. The two are not divorced. For instance, liberal democracy is absent if elections are used as a tool to legitimize authoritarian regimes. Liberal democracy is further compromised when authoritarian regimes create uneven political playing fields by subverting and politicising formal democratic institutions such as the judiciary and electoral bodies in order to gain unfair advantage over opposition political parties during elections.

For democracy to survive and flourish in Zimbabwe, Zimbabweans must possess the skills, attitudes, values and 
understand principles of democratic political systems to be able to access democracy. Elections therefore should give citizens the mandate to choose their representatives in accordance with the national constitution and electoral policies. The policies in turn influences the delimitation of constituencies, voter registration processes, ballot paper design and vote counting, these influence fairness and credibility of elections (Mapuva 2010). According to the Transparency International (2007) free and fair elections are characterised by the ability of prospective voters to access information on the eligibility to vote, how to register to vote and place, how to check and where to check the voters' roll, and how to address irregularities on voter information.

\section{Democratic Citizenship and Electoral Illiteracy}

Before looking at the term illiteracy, it is important to unpack concepts like citizenship and democratic citizenship. Although the notion of citizenship has been traced back to Ancient Greece, there is no consensus on citizenship's conceptual parameters as yet or its implications (Diamond 2002). From a sociological perspective, citizenship is broadly defined as 'a set of social practices which define the nature of social membership' (Turner 1993: 4). In this regard, citizenship relates to everyday life of people. It is concerned with how people give meaning to life on personal, socio-political and interpersonal levels. The concept of citizenship contains implications that go beyond the field of rights and duties arising from belonging to a politically defined community. It is a way of acting that evolves both in time and space. Citizenship links the citizen to a process of active participation in the community of belonging. According to Giroux (1989) citizenship is more inclined towards personal emancipation to more collective emancipation. For social contract theorists like Rousseau, Hobbes 
and Locke, the notion of citizenship is tied up with the evolution of the state. The state is an entity endowed with political sovereignty over a clearly defined territory that has a monopoly of the use of legitimate force and that consists of citizens whose loyalty is to the state (Giroux 1989). Citizenship in this respect is an instrument of social closure through which the state lays claim to and define its sovereignty, authority, legitimacy and identity. In this paper, the centrality of citizenship shall be viewed as that which promotes active participation by citizens and allow levels of engagement among the electorate so that the state can be able to provide for the common good of everybody (Aristotle 1958). What then is the common good of everybody in an election period? The answer to this rhetoric question shifts the focus of this paper to democratic citizenship which is another aspect to holding free, fair and credible elections. This paper argues that electoral crisis in Zimbabwe can only be addressed by effective and active citizenship. Active participation of citizens in an election without being exposed to intimidation and coercion are aspects of democratic citizenship.

The other aspect of democratic citizenship includes safeguarding democracy and citizenship rights and freedoms (Diamond 2002). A greater demonstration of democratic citizenship can be realised when citizens are free to elect their representatives in an election in a free environment. This is possible in a country where citizens demonstrate electoral literacy. Electoral literacy is defined as the knowledge and understanding of political processes and issues which enable people to perform their roles as citizens effectively, (Denver \& Hands 1990). Citizens have the duty and responsibility to choose how they are governed and who should govern them. Electoral literacy plays a major role when people are making such choices. In other words, electoral 
literacy refers to the basic concepts and facts that constitute a necessary condition of comprehending the contents of public debate. Citizens need to set goals for self-government, to understand political dynamics of the world as well as to be educated in processes and procedures of voting. The purpose of having electoral literacy is therefore to have informed political participation and choices. Observations by Denver \& Hands (1990) are that in most Third World countries, mostly in Africa the electorate lack the requisite electoral literacy and Zimbabwe provides a very good case study of that lack of electoral literacy despite having higher literate rate. This illiteracy will be explained as the discussion unfolds. In this regard, citizens who are literate in electoral processes should appreciate that belonging to Zimbabwe inevitably carries with it responsibilities for the country and that citizenship without participation is narrow and thus should be denounced.

Attention should now be turned to electoral illiteracy which is the main focus of this discussion. Electoral illiteracy involves the inability by citizens to fully understand why they are participating in elections. Electoral illiteracy also extends to include the inability by citizens (electorate) to question the electoral system in the event of electoral discrepancies. Illiteracy manifests if citizens can be manipulated during an election, and have their rights infringed resulting in compromising the credibility of election results. Illiteracy does not only make it difficult for people to cast their vote on the voting day, but makes it harder for them to engage with the subject, understand the processes behind it, and trust in the integrity of the political system. When citizens are not familiar with the electoral process, and not able to familiarise themselves with it, levels of participation

will remain low; 
additionally, a large number of improperly cast ballots or a dearth of confidence in the integrity of the elections or in the legitimacy of the results will follow. Such cynicism toward elections is especially likely to develop when election officials or political competitors have not fulfilled past promises. Although parties in Zimbabwe are allowed to have polling agents manning polling stations, this paper discovered that the majority of the agents in 2008, 2013 and 2018 elections did not know what they were expected to do as most of them were simply picked without prior training or education to become agents basing on their loyalty to their respective political parties. This is contrary to tenets of Democratic Citizenship (DC). Democratic citizenship entails the participation of people in politics that enhances the skills to organise for a better and inclusive democracy. Patrick (2011) extends electoral illiteracy to include the inability by citizens to question electoral processes in situations where there are discrepancies. Patrick further asserts that electoral manipulation is always rampant in circumstances where citizens are ignorant of their electoral systems thereby creating a sham election. For instance, in Zimbabwe, traditional chiefs, headman and kraal heads use their leadership positions to influence most rural voters to vote for the ruling party. In the 2008 and 2018 elections, registered voters were intimidated by traditional chiefs who commanded people in their constituencies to bring serial numbers of ballot papers that they will have used during the election to the local traditional leadership for a possible follow-up on who they would have voted for. There was intimidation and harassment of citizens due to their lack of electoral literacy. About $40 \%$ of the rural voting population submitted serial numbers of their ballot papers to their respective traditional leaders. It can therefore be concluded that the majority of Zimbabwe's rural populace voted in fear of 
being followed up and consequently voted for candidates not of their choice. Despite the presence of international observers in Zimbabwe's elections, a lot of electoral malpractices such as voter intimidation, politically motivated violence, and partisanship of the army and police who are expected to be non-partisan have been widespread.

\section{How People Behave at Election Time in Zimbabwe}

In this paper, voting behaviour is used to describe electoral activities which include participation in electoral campaigns, turnout at polling stations, and finally the choice of whom to vote for. When Zimbabwe held harmonised elections earlier in 2008, 2013 and 2018, choices made by people were driven by certain forces which rendered the whole process and outcome subjective and open to abuse. The drivers or factors noted include intimidation and fear, manipulation (vote buying), partisan and hero worshipping Masunungure 2013). Zembere (2015) observed rampant constitutional and political illiteracy in Zimbabwe during 2013 constitutional making process. The consequences of this lack of political knowledge are that the electorate is manipulated during election campaigns. For instance, a survey conducted after 2018 elections in Bindura revealed that people simply voted for parties basing on what they were told during campaigns by politicians. They were simply partisan in supporting and casting their votes without understanding the consequences of their decisions. For instance, in Zimbabwe war veterans and their dependence are less likely to be found supporting and voting for the opposition MDC. This indicates that the electorate in Zimbabwe are simply political fans who just love to follow their favourite teams even if they do not influence the outcome of games. They enjoy following political issues and cheering their favourite candidates, parties or ideologies 
which is the idea of hero worshipping (Somin 2013). Political fans much like sports fans are highly biased and overvalue anything that supports their pre-existing views. No wonder the political violence that culminated into killings and injuries of innocent people on August $1^{\text {st }} 2018$ in Zimbabwe as parties do not tolerate defeat. This is an indicator of political ignorance owing to electoral illiteracy. Sloganeering and political zeal are also ways used by politicians to attract voters than an understanding of respective political manifestos. In 2018 elections,slogans such as ED Pfee and Chamisa chete chete propelled the two candidates who were in a presidential race into a very tight contest because their followers were largely concerned about worshiping their heroes without caring about the issues that were being advanced by the candidates.

In Somin's (2013) view, political fans misinterpret simple data which they could have easily interpreted correctly in other context and are also prone to discussing political issues only with others who agree with their views and follow politics only through likeminded-media. Particularly with level of media control in third world countries an illiterate electorate cannot distinguish between the lies distributed and the untold truth which will never reach them anyway. Somin (2013) argued that most people do not precisely calculate the odds that their vote will make a difference but probably have an intuitive sense that the changes are very small and act accordingly. This is the reason some voters gave their votes to a party on the basis of promises and lies that have been told for close to half a century now. Others simply withdrew their vote. For instance, voter apathy was very high in 2008 rerun elections in Zimbabwe. Out of 6 million adult registered voters, only $38 \%$ of them voted in the July election compared to $59 \%$ who had voted in March that same year (Zembere 2018). 


\section{What Motivates People's Voting Choices}

Although there are several ways through which elections can be manipulated, the paper focuses on voter manipulation through violence, intimidation and caressing as impacting people's voting choices in Zimbabwe. However, although there are other factors that might play an important role in influencing people's voting choices, the use of violence has been widespread in Zimbabwe since 2000. Violence entails muscle power and can be unleashed on both literate and illiterate voters alike. Voters are coerced by the powerful politicians to satisfy their needs. Caressing as mentioned earlier on involves giving gifts to the electorate (Masunungure 2013).It is synonymous to vote buying.

Vote buying or caressing can take forms like monetary exchange and exchange for goods/gifts or services. The gifts that electorate receive when elections are approaching are meant to buy the voter and influence the voter's decisions. Gifts impose a form of identity on both the giver and the recipient and exchanges of gifts are governed by the norms of reciprocity.

In Zimbabwe's history of elections, it is common that the rural electorate receive gifts towards elections so that they continue to vote for the ruling party. For instance, during the 2008 campaign period, a number of populist initiatives such as Basic Commodities Supply Side Interventions (BACOSSI) and provision of farming inputs and equipment as part of post-resettlement support were launched by the Reserve Bank of Zimbabwe (RBZ) (Masunungure 2013). Other goodies were also distributed by the Zanu-PF leadership elite, including by the then First Lady, Grace Mugabe. At every rally addressed by the President just before the elections she donated large quantities of foodstuffs, including maize meal, sugar beans, cooking oil and salt. At one such rally, the statecontrolled media reported that Grace Mugabe 'donated food stuffs 
worth thousands of dollars to the Madamombe community. Among the food stuffs were 10 tonnes of maize meal, 10 tonnes of sugar beans, 2 tonnes of salt and 560 cases of $12 \times 2$ litres cooking oil' (Chipunza 2013). Although these actions were and are a violation of Part XIX of the Electoral Act which 'criminalises any gift, loan, offer or promise to or for any person in order to induce such person to produce or endeavour to procure the return of a candidate at an election or the vote of a voter at an election' (Constitution of Zimbabwe 2013), citizens are not in a position to question their candidates as the majority are not aware of the contents of the constitution regarding elections. Because of this lack of information, Zimbabweans engage in elections on the basis of their 'perception of self in relation to others; this perception effectively delineates and sets the domain of choice options perceived as available to an actor, both in an empirical and a moral sense' (Monroe \& Maher 1995: 12).

Gifts also come in the form of money, cloths, food handouts or hampers, while services include repairing of infrastructure such as roads, bridges, schools and donating books and second hand computers to schools. In Zimbabwe, vote buying is more rampant and effective in remote poverty stricken rural areas where electoral literacy rate is low. In accepting the gifts, the electorate (recipients) may be acting out of fear or genuine need due to poverty. Machiavelli in his book The Prince articulates how caressing can be used by authoritarian regimes to acquire and maximize power. All this according to Machiavelli is achieved through deceit and feigning double standards. Zimbabwe's 2008, 2013 and 2018 elections could be arguably described to meet Machiavelli's view of an authoritarian sitting government wanting to perpetuate the status quo (Mapuva 2010). The argument proffered in this paper is that Citizenship education is ideal as a 
means of strengthening democracy by challenging such antidemocratic practices of election manipulation.

For Masunungure (2013); Moore, (2013) voter manipulation is characterised by electoral malpractice that takes place before election time, during election time and after election time. These three categories involve the manipulation of rules that guide an election process and the voters. By manipulation of rules, it means electoral laws are distorted to favour one party in an election. The manipulation of voters is either to distort voter's preferences. Vote manipulation consists of mis-reporting, underprovision of voting facilities in opposition strongholds, lack of transparency in the organisation of elections, bias in the way electoral disputes are adjudicated in the courts (Norris 2014). Zimbabwe's 2018 election results have been contested in court. Opposition political parties felt the court case was tipped in favour of the ruling party. Mr Chamisa, leader of the Movement for Democratic Change Alliance went on to contest the court ruling which acknowledged Mnangagwa as the elected President. $\mathrm{Mr}$ Chamisa's case was dismissed by the courts as lacking the evidence that could be used in his favour (Zembere 2018). In Zimbabwe, the Judiciary, the Police and the Electoral Commission are politicised by the ruling party. For instance, the chief justice who adjudicated Chamisa's challenge on elections had been appointed by Mnangagwa five months before election time (ZESN 2018). He was a political appointee and would risk losing his job if the court ruled in Chamisa's favour.

Voter manipulation is also done through vote buying; it is mostly the illiterate, poor voters, unemployed and rural electorate who are targeted through the use of gifts to influence their vote. The structural role theory claims that low social status that emanates from low levels of education determines political 
behaviour. Lower people tend to make political choices based on influence coming from intimidation and voter buying without analysing the situation which is typical of illiterate people. According to the Zimbabwe Electoral Support Network (ZESN) (2016), the use of gifts to procure votes is illegal as per the constitution of Zimbabwe section 36 of the Electoral Act Chapter 2:13. Partisan distribution of food and agricultural inputs in a bid to secure votes is usually used by Zimbabwe's ruling party ZANU $\mathrm{PF}$ in every election since 2000. Rural electorate are now so conditioned to think that only ZANU PF have them at heart by extending a few gifts regardless of all the challenges that they experience in between elections. If these voters were literate enough, they would have been able to choose between sound leadership and occasional gifts used to lure them. It is due to electoral illiteracy and violence that voters are manipulated in very big ways. For instance, report from CSVR (2009) indicates that the extent of the violence and intimidation in Zimbabwe since 2000 has by percentage surpassed that of other SADC countries. Violence in Zimbabwe varied from election to election. Zimbabwe has held six elections since 1998 but the 2018 one leads all the other five elections in terms of post-election violence (RAU 2018). While elections in 2000, 2002, 2008 and 2013 were all violent, 2008 and 2018 leads in terms of pre-election and post-election violence respectively. Pre and post-election violence in Zimbabwe manifests in various forms such as abductions, assaults, attempted murder, death threats, burning of or stealing property, property destruction and torture are all more commonly applied forms of direct violence during election periods in Zimbabwe.

The aftermath of harmonised elections that took place in July 2018 has documented serious abuses in major cities of Zimbabwe. Violence erupted soon after the proclamation of 
election results (Zembere 2018). The post-election violence took a new twist with post-election violence resulting from a military crackdown on rioting youths resulting in the killing of six unarmed civilians and injuring many. Although the Minister of Justice Legal and Parliamentary Affairs assured the public that the presents of the army in public places was to maintain peace and tranquillity, the end result of security details in major towns triggered violence as security forces took control of major towns. Moreover, the presence of security details in presumably public places is on its own intimidation of the highest order.

The reasons for the 2018 election violence could be explained thus: it was the first election in Zimbabwe since 1980 without Mugabe on the ballot paper. Since 1980, only Mugabe had been voted for, first as a Prime Minister up to 1987 when the Unity Accord introduced a presidential system that same year through a constitutional amendment. So, the significance of the 2018 election cannot be under estimated. The election was important to both Zimbabweans and the international world because people anticipated a much awaited regime change.

\section{Implications of Democratic Citizenship to Challenges of Electoral Illiteracy}

As stated earlier in the document, electoral processes provide necessary conditions for democratic societies, as well as confer legitimacy and credibility on elected governments. However, legitimacy is only afforded if the larger portion of citizens participates in an election without being coerced, intimidated or harassed. Although voter turnout has been very high in Zimbabwe's harmonised elections of 2008 and 2013, the general public were driven to voting stations by their traditional chiefs who made sure every adult within their chieftaincy had voted for the 
ruling party. For the past decade, elections in Zimbabwe created a crisis of confidence as they were undemocratic. Very few people participated in the elections willingly. The general public voted under duress. This explains the violence which always breaks out after the announcing of election results.

\section{Conclusion}

The purpose of this article has been to examine how electoral illiteracy plays a part in citizen's political participation. The paper concludes that voter participation in 2008, 2013 and 2018 elections in Zimbabwe was driven by the need to gain from financial and material gifts distributed by politicians during the election period. The paper further illustrates that the number of actual voters in July 2008 election rerun remained lower than the number of registered voters. There was high voter apathy due to political intimidation and electoral violence.

Throughout this discussion, the researcher has attempted to show that democratic citizenship (DC) can only function properly if citizens are informed about and allowed to exercise their political rights. Limited political knowledge exposes citizens to gross manipulation by politicians despite their level of literacy, rendering democratic citizenship meaningless. To overcome the negative impact of illiteracy on citizen participation, this research therefore recommends voter education programs in Zimbabwe. Firstly, voter education programs can assist electorally illiterate men and women in becoming politically active, so that they are not disenfranchised due to lack of electoral knowledge. 
Monicah Zembere

School of Education

University of Witwatersrand

South Africa

Monizembere69@gmail.com

\section{References}

Aristotle, (1958). Politics (ed. and transl. by Ernest Baker). London, Oxford University Press.

Chipunza, P. (2013). 'First Lady rallies voters to President, ZanuPF'. The Herald, 18 July.

Diamond, L. (2002). 'Elections without Democracy: Thinking About Hybrid Regimes'. Journal of Democracy 13(2).

CSVR, (2009), Subliminal Terror? Human rights violations and torture in Zimbabwe during2008. June 2009. Johannesburg: CSVR [long report]

Giroux, H. A. (1989). Theory and resistance in education: A pedagogy for the opposition. New York, NY: Bergin \& Garvey.

Heater, D. (2004a). Citizenship: The civic ideal in world history, politics and education. Manchester: Manchester University Press.

Masunungure, E. (2013). The 'Menu of Manipulation' and the 2013 Zimbabwe Elections: Towards Explaining the 'Technical Knockout' Journal of Elections. 
Mapuva, (2013). 'Militarization of public Institutions, flawed Electoral Processes and Curtailed Citizen Participation.Legislative Stud.

Moore, H. M. (2013). Public value governance: Moving beyond traditional public administration and the new public management. Routledge, New York.

Norris, P. (2004). Electoral Engineering: Voting Rules and Political Behaviour. Cambridge: Cambridge University Press.

Norris, P. (2014). Why electoral integrity matters. Cambridge University Press. Cambridge.

Raftopoulos, B. (2013b). 'The 2013 Elections in Zimbabwe: The End of an Era'. Journal of Southern African Studies 39(4).

RAU. (2016). Are former liberation movements inherently violent as governments? February 2016. Harare: Research \& Advocacy Unit.

RAU. (2016). A valedictory for civil society in Zimbabwe. February 2016. Harare: Research \& Advocacy.

Somin, I. (2013).Democracy and Political Ignorance. Cato Unbound.

Zembere, M. (2018). Democratic citizenship Education in Zimbabwe and its implications for teaching and learning.Sun Scolar. Stellenbosch University. South Africa.

Zimbabwe Electoral Support Network. (2016). ZESN Condemns Vote Buying and Intimidation in Chimanimani West. Harare.

Zimbabwe Electoral Support Network. (2017). Enhancing Citizen Participation in Electoral Processes through Voter Education. Zimbabwe. 